\title{
Nocardioides daedukensis sp. nov., a halotolerant bacterium isolated from soil
}

\author{
Jung-Hoon Yoon, Sooyeon Park, So-Jung Kang, Jung-Sook Lee, \\ Keun Chul Lee and Tae-Kwang Oh
}

Correspondence
Jung-Hoon Yoon
jhyoon@kribb.re.kr Korea Research Institute of Bioscience and Biotechnology (KRIBB), PO Box 115, Yusong, Taejon,
Republic of Korea

\begin{abstract}
A Gram-positive, non-motile and rod- or coccoid-shaped bacterial strain, MDN22 ${ }^{\top}$, was isolated from a soil sample from Korea. Strain MDN22 ${ }^{\top}$ grew optimally at $\mathrm{pH} 7.0-8.0$, at $30{ }^{\circ} \mathrm{C}$ and in the presence of $0-0.5 \%(\mathrm{w} / \mathrm{v}) \mathrm{NaCl}$. Phylogenetic analyses based on $16 \mathrm{~S}$ rRNA gene sequences showed that strain MDN22 ${ }^{\top}$ was phylogenetically most closely related to the genera Nocardioides and Marmoricola. In the neighbour-joining phylogenetic tree, strain MDN22 ${ }^{\top}$ was most closely related to Nocardioides jensenii KCTC $9134^{\top}$, with which it exhibited 98.3\% 16S rRNA gene sequence similarity. The strain exhibited 93.1-96.9\% and 95.3-95.9\% 16S rRNA gene sequence similarities to the type strains of other species of the genera Nocardioides and Marmoricola, respectively. The chemotaxonomic properties of strain $\mathrm{MDN}^{2} 2^{\top}$ were consistent with those of the genus Nocardioides; the cell-wall peptidoglycan type was based on LL-2,6diaminopimelic acid, the predominant menaquinone was $\mathrm{MK}-8\left(\mathrm{H}_{4}\right)$ and the major fatty acids were iso- $\mathrm{C}_{16: 0}$ and $\mathrm{C}_{17: 1}$. The DNA G $+\mathrm{C}$ content was 68.7 mol\%. DNA-DNA relatedness data and differential phenotypic properties suggested that strain $\mathrm{MDN}_{2} 2^{\top}$ could be differentiated from $N$. jensenii and Nocardioides dubius. On the basis of the data obtained, strain MDN22 ${ }^{\top}$ is considered to represent a novel species of the genus Nocardioides, for which the name Nocardioides daedukensis sp. nov., is proposed. The type strain is $\mathrm{MDN}^{2} 2^{\top}$ (=KCTC $19601^{\top}=$ CCUG $57505^{\top}$ ).
\end{abstract}

The genus Nocardioides was first proposed by Prauser (1976) with a single species, Nocardioides albus. Phylogenetically, the genus forms its evolutionary lineage within the family Nocardioidaceae of the suborder Propionibacterineae (Stackebrandt et al., 1997). Recently, increasing numbers of descriptions of novel species, e.g. 9 species in 2008, have enlarged the size of the genus Nocardioides (Euzéby, 1997). At the time of writing, the genus Nocardioides comprises at least 36 species with validly published names (Euzéby, 1997). In this study, we describe a halotolerant bacterial strain, $\mathrm{MDN}_{2} 2^{\mathrm{T}}$, which was isolated from a soil sample from Korea, and establish its taxonomic position by using a polyphasic approach that included the determination of phenotypic and chemotaxonomic properties and a detailed phylogenetic investigation based on 16S rRNA gene sequences.

Strain MDN22 ${ }^{\mathrm{T}}$ was isolated by means of the standard dilution-plating technique on $10 \times$ diluted nutrient agar (NA; Difco) at $30{ }^{\circ} \mathrm{C}$. Nocardioides jensenii KCTC $9134^{\mathrm{T}}$ and Nocardioides dubius KSL-104 ${ }^{\mathrm{T}}$ were used as reference strains for DNA-DNA hybridization, fatty acid analysis

The GenBank/EMBL/DDBJ accession number for the 16S rRNA gene sequence of strain MDN22 ${ }^{\top}$ is FJ842646. and phenotypic characterization. N. jensenii KCTC $9134^{\mathrm{T}}$ was obtained from the KCTC, Taejon, Korea, and $N$. dubius KSL-104 ${ }^{\mathrm{T}}$ was obtained from our previous study (Yoon et al., 2005b). The morphological, physiological and biochemical characteristics of strain MDN $22^{\mathrm{T}}$ were investigated using routine cultivation at $30{ }^{\circ} \mathrm{C}$ on NA and were determined as described by Yoon et al. (2005a). Cultural properties were examined as described by Yoon et al. (2005a): growth at various temperatures $(4,10,20,25,28$, $30,35,37,40$ and $45^{\circ} \mathrm{C}$ ) was measured on NA; growth with various $\mathrm{NaCl}$ concentrations $(0,0.5$ and $1.0-10.0 \%$, $\mathrm{w} / \mathrm{v}$, in increments of $1 \%$ ) was investigated in trypticase soy broth prepared according to the formula of the Difco medium except that $\mathrm{NaCl}$ was excluded from the formula; and growth at various $\mathrm{pH}$ values was determined in nutrient broth (NB; Difco) adjusted to $\mathrm{pH} 4.5-10.5$ in increments of $0.5 \mathrm{pH}$ units by the addition of $\mathrm{HCl}$ or $\mathrm{Na}_{2} \mathrm{CO}_{3}$. Susceptibility to antibiotics was tested by placing antibiotic-impregnated discs on NA plates that were seeded with suspensions of the test strain. Enzyme activities and other physiological and biochemical properties were tested by using the API ZYM and API 20E systems (bioMérieux), respectively. Utilization of various substrates as sole carbon and energy sources was determined as described by Shirling \& Gottlieb (1966). The morphological, cultural, physiological 
and biochemical characteristics of strain $\mathrm{MDN} 22^{\mathrm{T}}$ are given in Table 1 and in the species description.

Cell biomass for DNA extraction and for the analyses of cell-wall components, isoprenoid quinones and polar lipids was obtained from cultures grown in NB for 7 days at $30{ }^{\circ} \mathrm{C}$. For cellular fatty acid analysis, cell mass of strain MDN22 ${ }^{\mathrm{T}}$, N. jensenii KCTC $9134^{\mathrm{T}}$ and N. dubius KSL-104 ${ }^{\mathrm{T}}$ was harvested from NA plates after cultivation for 7 days at $30{ }^{\circ} \mathrm{C}$. Molecular systematic and chemotaxonomic properties were examined as described by Yoon et al. (2005a, b). Alignment of $16 \mathrm{~S}$ rRNA gene sequences was carried out with CLUSTAL W software (Thompson et al., 1994). Gaps at the $5^{\prime}$ and $3^{\prime}$ ends of the alignment were omitted from further analysis. Phylogenetic trees were inferred by using three tree-making algorithms in the PHYLIP package
(Felsenstein, 1993), i.e. neighbour-joining (Saitou \& Nei, 1987), maximum-likelihood (Felsenstein, 1981) and maximum-parsimony (Kluge \& Farris, 1969) methods. Evolutionary distance matrices for the neighbour-joining method were calculated with the algorithm of Jukes \& Cantor (1969) with the DNADIST program. The isomer of the diamino acid in the cell-wall peptidoglycan was analysed using TLC according to the method described by Komagata \& Suzuki (1987). The fatty acids were extracted and fatty acid methyl esters were prepared according to the standard protocol of the MIDI/Hewlett Packard Microbial Identification System (Sasser, 1990). DNA-DNA hybridization was performed fluorometrically according to the procedure of Ezaki et al. (1989) using photobiotin-labelled DNA probes and microdilution wells. Hybridization was performed by using five replications for

Table 1. Differential phenotypic characteristics of strain $M D N 22^{\top}, N$. jensenii and $N$. dubius

Strains: 1, MDN22 $2^{\mathrm{T}} ; 2$, N. jensenii KCTC $9134^{\mathrm{T}} ; 3$, N. dubius KSL-104 ${ }^{\mathrm{T}}$. Data are taken from Collins et al. (1989), Yi \& Chun (2004), Yoon et al. (2005b) and this study. All strains are rods/cocci and give a positive result for Gram-staining, catalase, hydrolysis of casein and gelatin, activity of esterase lipase (C8) and leucine arylamidase, and for the utilization of acetate and pyruvate. All strains are negative for hydrolysis of starch, for activities of lipase (C14), valine and cystine arylamidase, trypsin, $\alpha$-chymotrypsin, acid phosphatase, $\alpha$ - and $\beta$ galactosidase, $\beta$-glucuronidase, $N$-acetyl- $\beta$-glucosaminidase, $\alpha$-mannosidase and $\alpha$-fucosidase and for the utilization of L-arabinose, cellobiose, D-fructose, D-galactose, maltose, D-mannose, D-xylose, benzoate, citrate, formate and succinate. + , Positive; $\mathrm{w}$, weakly positive; - , negative.

\begin{tabular}{|c|c|c|c|}
\hline Characteristic & 1 & 2 & 3 \\
\hline Cell size $(\mu \mathrm{m})$ & $0.4-0.8 \times 0.8-3.0$ & $0.6-1.0 \times 2.0-7.0$ & $0.8-1.0 \times 1.5-2.5$ \\
\hline Motility & - & - & + \\
\hline Oxidase & + & - & + \\
\hline Nitrate reduction & + & + & - \\
\hline \multicolumn{4}{|l|}{ Hydrolysis of: } \\
\hline Aesculin & + & - & + \\
\hline Hypoxanthine & - & + & - \\
\hline Tween 80 & + & + & - \\
\hline Tyrosine & - & + & - \\
\hline Urea & - & + & - \\
\hline Xanthine & - & + & - \\
\hline \multicolumn{4}{|l|}{ Utilization of: $^{*}$} \\
\hline D-Glucose & - & + & + \\
\hline L-Glutamate & - & + & + \\
\hline L-Malate & + & + & - \\
\hline Salicin & - & - & $\mathrm{W}$ \\
\hline Sucrose & - & + & - \\
\hline Trehalose & + & + & - \\
\hline \multicolumn{4}{|c|}{ Enzyme activity (API ZYM)* } \\
\hline Alkaline phosphatase & - & + & $\mathrm{W}$ \\
\hline Esterase $(\mathrm{C} 4)$ & - & + & $\mathrm{w}$ \\
\hline $\begin{array}{l}\text { Naphthol-AS-BI- } \\
\text { phosphohydrolase }\end{array}$ & $\mathrm{w}$ & + & $\mathrm{w}$ \\
\hline$\alpha$-Glucosidase & - & - & + \\
\hline$\beta$-Glucosidase & - & - & + \\
\hline DNA G + C mol\% & 68.7 & 68.8 & 70.6 \\
\hline
\end{tabular}

${ }^{\star}$ Data for carbon source utilization and enzyme activity for N. jensenii KCTC $9134^{\mathrm{T}}$ and N. dubius KSL-104 ${ }^{\mathrm{T}}$ were taken from this study. 
each sample. The highest and lowest values obtained in each sample were excluded and the means of the remaining three values were quoted as DNA-DNA relatedness values.

The almost-complete 16S rRNA gene sequence of strain MDN22 ${ }^{\mathrm{T}}$ determined in this study comprised 1475 nucleotides (approx. $96 \%$ of the Escherichia coli sequence). Comparative analysis of $16 \mathrm{~S}$ rRNA gene sequences revealed that strain $\mathrm{MDN} 22^{\mathrm{T}}$ is phylogenetically most closely related to members of the genera Nocardioides and Marmoricola at the periphery of the phylogenetic radiation encompassed by the genus Nocardioides (Yoon et al., 2005b; Lee, 2007; Dastager et al., 2008). In the neighbour-joining phylogenetic tree, strain $\mathrm{MDN} 22^{\mathrm{T}}$ clustered with $N$. jensenii KCTC $9134^{\mathrm{T}}$ with a bootstrap resampling value of $73.2 \%$ and this cluster joined the cluster comprising species of the genus Marmoricola with a bootstrap resampling value of $96.0 \%$ (Fig. 1). These relationships were also found in the tree constructed using the maximum-likelihood algorithm
(Fig. 1). Strain $\mathrm{MDN}_{22} 2^{\mathrm{T}}$ exhibited $16 \mathrm{~S}$ rRNA gene sequence similarity values of $98.3,96.9$ and $93.1-96.2 \%$ with $N$. jensenii KCTC $9134^{\mathrm{T}}, N$. dubius KSL-104 ${ }^{\mathrm{T}}$ and the type strains of other species of the genus Nocardioides, respectively, and $95.3-95.9 \%$ with the type strains of members of the genus Marmoricola.

Strain MDN22 ${ }^{\mathrm{T}}$ had LL-2,6-diaminopimelic acid as the diagnostic diamino acid in the cell-wall peptidoglycan. The predominant isoprenoid quinone found in strain $\mathrm{MDN} 22^{\mathrm{T}}$ was menaquinone- $8\left(\mathrm{H}_{4}\right)$. The cellular fatty acid profile of strain MDN22 ${ }^{\mathrm{T}}$ is given in Table 2, together with those of $N$. jensenii KCTC $9134^{\mathrm{T}}$ and $N$. dubius KSL-104 ${ }^{\mathrm{T}}$, which were also analysed in this study. The fatty acid profile of strain MDN $22^{\mathrm{T}}$ was similar to those of the other species of the genus Nocardioides as well as N. jensenii KCTC $9134^{\mathrm{T}}$ and $N$. dubius KSL-104 $4^{\mathrm{T}}$ in that iso- $\mathrm{C}_{16: 0}$ was the predominant fatty acid (Yoon et al., 1997, 1999; Yoon \& Park, 2006; Kim et al., 2009). The DNA G + C content of

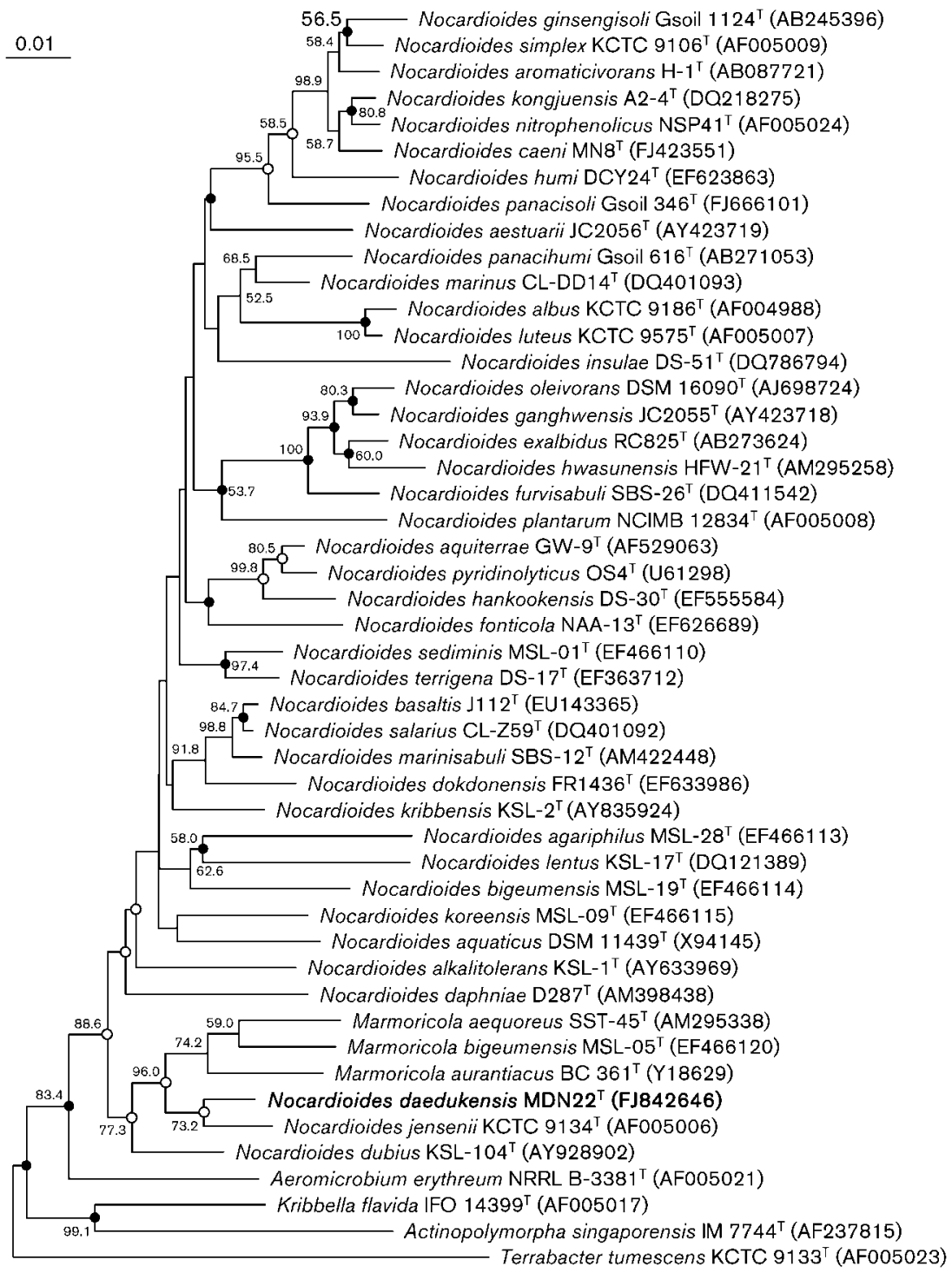

Fig. 1. Neighbour-joining phylogenetic tree based on 16S rRNA gene sequences showing the positions of strain MDN22 ${ }^{\top}$, species of the genus Nocardioides and some other related taxa. Bootstrap values $(>50 \%)$ based on 1000 replications are shown at branch nodes. Filled circles indicate that the corresponding nodes were also recovered in the trees generated with the maximum-likelihood and maximum-parsimony algorithms. Open circles indicate that the corresponding nodes were also recovered in the tree generated with the maximum-likelihood algorithm. Terrabacter tumescens KCTC $9133^{\top}$ was used as an outgroup. Bar, 0.01 substitutions per nucleotide position. 
Table 2. Cellular fatty acid compositions of strain $M D N 22^{\top}, N$. jensenii KCTC $9134^{\top}$, N. dubius KSL-104 ${ }^{\top}$ and three species of the genus Marmoricola

Strains: $1, \mathrm{MDN} 22^{\mathrm{T}} ; 2$, N. jensenii KCTC $9134^{\mathrm{T}}$; 3, N. dubius KSL$104^{\mathrm{T}}$; 4, M. aurantiacus BC $361^{\mathrm{T}}$ (data from Urzì et al., 2000); 5, M. aequoreus SST $-45^{\mathrm{T}}$ (Lee, 2007); 6, M. bigeumensis MSL- $05^{\mathrm{T}}$ (Dastager et al., 2008). Data for columns 1-3 were taken from this study. -, Values $<1.0 \%$ or not detected; ND, no data available.

\begin{tabular}{|c|c|c|c|c|c|c|}
\hline Fatty acid (\%) & 1 & 2 & 3 & 4 & 5 & 6 \\
\hline \multicolumn{7}{|l|}{ Straight-chain } \\
\hline $\mathrm{C}_{14: 0}$ & - & - & - & 3.4 & 1.4 & $\mathrm{ND}$ \\
\hline $\mathrm{C}_{16: 0}$ & 0.6 & 2.6 & 1.1 & 41.4 & 35.0 & 4.0 \\
\hline $\mathrm{C}_{17: 0}$ & 1.4 & 1.1 & - & - & 2.9 & ND \\
\hline $\mathrm{C}_{18: 0}$ & 1.4 & 2.9 & 1.8 & 2.4 & 7.6 & ND \\
\hline \multicolumn{7}{|l|}{ Branched } \\
\hline iso- $\mathrm{C}_{14: 0}$ & - & - & 3.0 & - & - & 3.3 \\
\hline iso- $\mathrm{C}_{15: 0}$ & 1.2 & 4.0 & 1.9 & - & - & $\mathrm{ND}$ \\
\hline iso- $\mathrm{C}_{16: 0}$ & 40.9 & 33.4 & 57.8 & - & - & 59.1 \\
\hline iso- $\mathrm{C}_{16: 1}$ & 3.5 & 10.9 & 5.1 & - & - & $\mathrm{ND}$ \\
\hline iso- $\mathrm{C}_{17: 0}$ & - & 2.1 & 2.4 & - & - & $\mathrm{ND}$ \\
\hline anteiso- $\mathrm{C}_{17: 0}$ & - & 1.4 & 1.7 & - & - & 6.9 \\
\hline iso- $\mathrm{C}_{18: 0}$ & 2.7 & 1.2 & 3.0 & - & - & ND \\
\hline \multicolumn{7}{|l|}{ Unsaturated } \\
\hline $\mathrm{C}_{16: 1}$ & - & - & - & 14.9 & 6.6 & $\mathrm{ND}$ \\
\hline$C_{17: 1}$ & 15.5 & 10.1 & 1.4 & - & 2.0 & ND \\
\hline $\mathrm{C}_{18: 1}$ & 7.6 & 4.6 & 2.8 & 33.7 & 40.1 & ND \\
\hline \multicolumn{7}{|l|}{ 10-Methyl } \\
\hline $\mathrm{C}_{16: 0}$ & 0.7 & 6.4 & 5.3 & - & - & $\mathrm{ND}$ \\
\hline$C_{17: 0}$ & 12.2 & 5.5 & 8.6 & - & - & $\mathrm{ND}$ \\
\hline $\mathrm{C}_{18: 0}$ & 6.3 & 9.3 & - & 2.8 & - & $\mathrm{ND}$ \\
\hline \multicolumn{7}{|l|}{ Hydroxy } \\
\hline $\mathrm{C}_{17: 0} 3-\mathrm{OH}$ & 1.2 & - & - & - & - & ND \\
\hline Summed feature $3^{\star}$ & 1.4 & 1.8 & 1.0 & - & - & $\mathrm{ND}$ \\
\hline
\end{tabular}

* Summed features represent two or three fatty acids that cannot be separated by the Microbial Identification System. Summed feature 3 consisted of $\mathrm{C}_{16: 1} \omega 7 c$ and/or iso- $\mathrm{C}_{15: 0} 2-\mathrm{OH}$.

strain MDN22 ${ }^{\mathrm{T}}$ was $68.7 \mathrm{~mol} \%$. The major polar lipids detected in strain $\mathrm{MDN} 22^{\mathrm{T}}$ were diphosphatidylglycerol, an unidentified phospholipid and two unidentified lipids; minor amounts of phosphatidylglycerol and phosphatidylethanolamine and an unidentified phospholipid were also detected. The polar lipid profile of strain $\mathrm{MDN}_{2} 2^{\mathrm{T}}$ was similar to those of N. jensenii KCTC $9134^{\mathrm{T}}$ and N. dubius KSL- $104^{\mathrm{T}}$ in that diphosphatidylglycerol and phosphatidylglycerol are present in strain MDN22 ${ }^{\mathrm{T}}$, but different in that phosphatidylinositol was absent in strain $\mathrm{MDN} 22^{\mathrm{T}}$ (Collins et al., 1989; Yoon et al., 2005b). The results of the chemotaxonomic analyses, showing that strain MDN $22^{\mathrm{T}}$ was similar in its properties to species of the genus Nocardioides, were in agreement with the result of phylogenetic analysis. Strain $\mathrm{MDN} 22^{\mathrm{T}}$ exhibited higher $16 \mathrm{~S}$ rRNA gene sequence similarities with the type strains of $N$. jensenii and $N$. dubius than with members of the genus Marmoricola and its fatty acid profile was clearly distinguishable from those of the type strains of Marmoricola aurantiacus, the type species of the genus, and Marmoricola aequoreus (Urzì et al., 2000; Dastager et al., 2008; Table 2). Accordingly, it is reasonable to classify strain $\mathrm{MDN} 22^{\mathrm{T}}$ as a member of the genus Nocardioides.

Strain MDN22 ${ }^{\mathrm{T}}$ exhibited mean DNA-DNA relatedness values of 19 and $10 \%$ with $N$. jensenii KCTC $9134^{\mathrm{T}}$ and $N$. dubius KSL- $104^{\mathrm{T}}$, respectively. Strain MDN $22^{\mathrm{T}}$ was distinguishable from $N$. jensenii and $N$. dubius by differences in several phenotypic characteristics as shown in Table 1 . The phylogenetic distinctiveness of strain MDN $22^{\mathrm{T}}$ with respect to the other species of the genus Nocardioides, together with the genetic distinctiveness and differential phenotypic properties between strain $\mathrm{MDN} 22^{\mathrm{T}}$ and the two most closely phylogenetically related members of the genus Nocardioides, are sufficient to support the suggestion that it represents a separate species from the recognized species of the genus Nocardioides (Wayne et al., 1987; Stackebrandt \& Goebel, 1994). On the basis of the data presented, strain MDN22 ${ }^{\mathrm{T}}$ represents a novel species of the genus Nocardioides, for which the name Nocardioides daedukensis sp. nov. is proposed.

\section{Description of Nocardioides daedukensis sp. nov.}

Nocardioides daedukensis (dae.duk.en'sis. N.L. masc. adj. daedukensis pertaining to Daeduk Science Park, the location of the Korea Research Institute of Bioscience and Biotechnology, where taxonomic studies of this species were performed).

Cells are aerobic, non-spore-forming, non-motile rods or cocci $(0.4-0.8 \times 0.8-3.0 \mu \mathrm{m})$. Cells show rod-to-coccus morphogenesis from the early exponential phase to the stationary phase. Gram-staining-positive, but Gramstaining-variable in old cultures. Colonies on NA are circular, raised, glistening, smooth, pale yellow in colour and $1.0-1.5 \mathrm{~mm}$ in diameter after incubation for 7 days at $30{ }^{\circ} \mathrm{C}$. Neither substrate nor aerial mycelium is formed. Optimal temperature for growth is $30{ }^{\circ} \mathrm{C}$. Growth occurs at 4 and $37{ }^{\circ} \mathrm{C}$, but not at $40{ }^{\circ} \mathrm{C}$. Optimal $\mathrm{pH}$ for growth is $\mathrm{pH} 7.0-8.0$. Growth occurs at $\mathrm{pH} 6.0$ and 10.0, but not at $\mathrm{pH} 5.5$ or 10.5. Growth occurs in the presence of $0-9.0 \%$ (w/v) $\mathrm{NaCl}$ with an optimum in the presence of $0-0.5 \%$ $(\mathrm{w} / \mathrm{v}) \mathrm{NaCl}$. Arginine dihydrolase, lysine decarboxylase, ornithine decarboxylase and tryptophan deaminase activities are absent. $\mathrm{H}_{2} \mathrm{~S}$ and indole are not produced. Tweens 20, 40 and 60 are hydrolysed. Susceptible to the following antibiotics ( $\mu \mathrm{g}$ per disc unless otherwise stated): carbenicillin (100), cephalothin (30), chloramphenicol (100), gentamicin (30), kanamycin (30), lincomycin (15), neomycin (30), oleandomycin (15), penicillin G (20 U), polymyxin B (100 U), streptomycin (50) and tetracycline (30). Resistant to the following antibiotics: ampicillin (10) and novobiocin (5). The cell-wall peptidoglycan is based on LL-2,6-diaminopimelic acid. The predominant menaquinone is $\mathrm{MK}-8\left(\mathrm{H}_{4}\right)$. The major fatty acids $(>10 \%$ of 
total fatty acids) are iso- $\mathrm{C}_{16: 0}, \mathrm{C}_{17: 1}$ and 10-methyl- $\mathrm{C}_{17: 0}$. The major polar lipids are diphosphatidylglycerol, an unidentified phospholipid and two unidentified lipids. Other phenotypic characteristics are given in Table 1.

The type strain, MDN22 ${ }^{\mathrm{T}} \quad\left(=\mathrm{KCTC} \quad 19601^{\mathrm{T}}=\mathrm{CCUG}\right.$ $\left.57505^{\mathrm{T}}\right)$, was isolated from a soil at Taejon, Korea. The DNA $\mathrm{G}+\mathrm{C}$ content of the type strain is $68.7 \mathrm{~mol} \%$ (HPLC).

\section{Acknowledgements}

This work was supported by the 21C Frontier Program of Microbial Genomics and Applications (grant MG05-0401-2-0) from the Ministry of Education, Science and Technology (MEST) of the Republic of Korea.

\section{References}

Collins, M. D., Dorsch, M. \& Stackebrandt, E. (1989). Transfer of Pimelobacter tumescens to Terrabacter gen. nov. as Terrabacter tumescens comb. nov. and of Pimelobacter jensenii to Nocardioides as Nocardioides jensenii comb. nov. Int J Syst Bacteriol 39, 1-6.

Dastager, S. G., Lee, J.-C., Ju, Y.-J., Park, D.-J. \& Kim, C.-J. (2008). Marmoricola bigeumensis sp. nov., a member of the family Nocardioidaceae. Int J Syst Evol Microbiol 58, 1060-1063.

Euzéby, J. P. (1997). List of Bacterial Names with Standing in Nomenclature: a folder available on the Internet. (Last full update: 6 February 2009). http://www.bacterio.net

Ezaki, T., Hashimoto, Y. \& Yabuuchi, E. (1989). Fluorometric deoxyribonucleic acid-deoxyribonucleic acid hybridization in microdilution wells as an alternative to membrane filter hybridization in which radioisotopes are used to determine genetic relatedness among bacterial strains. Int J Syst Bacteriol 39, 224-229.

Felsenstein, J. (1981). Evolutionary trees from DNA sequences: a maximum likelihood approach. J Mol Evol 17, 368-376.

Felsenstein, J. (1993). PHYLIP (phylogeny inference package) version 3.5c. Distributed by the author. Department of Genome Sciences, University of Washington, Seattle, USA.

Jukes, T. H. \& Cantor, C. R. (1969). Evolution of protein molecules. In Mammalian Protein Metabolism, vol. 3, pp. 21-132. Edited by H. N. Munro. New York: Academic Press.

Kim, K.-H., Roh, S. W., Chang, H.-W., Nam, Y.-D., Yoon, J.-H., Jeon, C. O., Oh, H.-M. \& Bae, J.-W. (2009). Nocardioides basaltis sp. nov., isolated from black beach sand. Int J Syst Evol Microbiol 59, 42-47.

Kluge, A. G. \& Farris, J. S. (1969). Quantitative phyletics and the evolution of anurans. Syst Zool 18, 1-32.

Komagata, K. \& Suzuki, K. (1987). Lipid and cell-wall analysis in bacterial systematics. Methods Microbiol 19, 161-207.
Lee, S. D. (2007). Marmoricola aequoreus sp. nov., a novel actinobacterium isolated from marine sediment. Int J Syst Evol Microbiol 57, 1391-1395.

Prauser, H. (1976). Nocardioides, a new genus of the order Actinomycetales. Int J Syst Bacteriol 26, 58-65.

Saitou, N. \& Nei, M. (1987). The neighbor-joining method: a new method for reconstructing phylogenetic trees. Mol Biol Evol 4, 406425.

Sasser, M. (1990). Identification of bacteria by gas chromatography of cellular fatty acids, MIDI Technical Note 101. Newark, DE: MIDI Inc.

Shirling, E. B. \& Gottlieb, D. (1966). Methods for characterization of Streptomyces species. Int J Syst Bacteriol 16, 313-340.

Stackebrandt, E. \& Goebel, B. M. (1994). Taxonomic note: a place for DNA-DNA reassociation and 16S rRNA sequence analysis in the present species definition in bacteriology. Int J Syst Bacteriol 44, 846849.

Stackebrandt, E., Rainey, F. A. \& Ward-Rainey, N. L. (1997). Proposal for a new hierarchic classification system, Actinobacteria classis nov. Int J Syst Bacteriol 47, 479-491.

Thompson, J. D., Higgins, D. G. \& Gibson, T. J. (1994). CLUSTAL W: improving the sensitivity of progressive multiple sequence alignment through sequence weighting, position specific gap penalties and weight matrix choice. Nucleic Acids Res 22, 4673-4680.

Urzì, C., Salamone, P., Schumann, P. \& Stackebrandt, E. (2000). Marmoricola aurantiacus gen. nov., sp. nov., a coccoid member of the family Nocardioidaceae isolated from a marble statue. Int J Syst Evol Microbiol 50, 529-536.

Wayne, L. G., Brenner, D. J., Colwell, R. R., Grimont, P. A. D., Kandler, O., Krichevsky, M. I., Moore, L. H., Moore, W. E. C., Murray, R. G. E. \& other authors (1987). International Committee on Systematic Bacteriology. Report of the ad hoc committee on reconciliation of approaches to bacterial systematics. Int J Syst Bacteriol 37, 463-464.

Yi, H. \& Chun, J. (2004). Nocardioides ganghwensis sp. nov., isolated from tidal flat sediment. Int J Syst Evol Microbiol 54, 1295-1299.

Yoon, J.-H. \& Park, Y.-H. (2006). The genus Nocardioides. In The Prokaryotes, 3rd edn, vol. 3, pp. 1099-1113. Edited by M. Dworkin, S. Falkow, E. Rosenberg, K. H. Schleifer \& E. Stackebrandt. New York: Springer.

Yoon, J.-H., Rhee, S.-K., Lee, J.-S., Park, Y.-H. \& Lee, S. T. (1997). Nocardioides pyridinolyticus sp. nov., a pyridine-degrading bacterium isolated from the oxic zone of an oil shale column. Int J Syst Bacteriol 47, 933-938.

Yoon, J.-H., Cho, Y.-G., Lee, S. T., Suzuki, K.-I., Nakase, T. \& Park, Y.-H. (1999). Nocardioides nitrophenolicus sp. nov., a p-nitrophenoldegrading bacterium. Int J Syst Bacteriol 49, 675-680.

Yoon, J.-H., Kim, I.-G., Lee, M.-H., Lee, C.-H. \& Oh, T.-K. (2005a). Nocardioides alkalitolerans sp. nov., isolated from an alkaline serpentinite soil in Korea. Int J Syst Evol Microbiol 55, 809-814.

Yoon, J.-H., Lee, C.-H. \& Oh, T.-K. (2005b). Nocardioides dubius sp. nov., isolated from an alkaline soil. Int J Syst Evol Microbiol 55, 22092212 . 